\title{
The contribution of FTO and UCP-1 SNPs to extreme obesity, diabetes and cardiovascular risk in Brazilian individuals
}

\author{
Adauto V Ramos ${ }^{1,2}$, Luciana Bastos-Rodrigues ${ }^{1}$, Bruna A Resende ${ }^{1}$, Eitan Friedman ${ }^{3}$, Luciana Campanha-Versiani ${ }^{1}$,
} Debora M Miranda ${ }^{4}$, Marta Sarquis ${ }^{5}$ and Luiz De Marco ${ }^{1 *}$

\begin{abstract}
Background: Obesity has become a common human disorder associated with significant morbidity and mortality and adverse effects on quality of life. Sequence variants in two candidate genes, FTO and UCP-1, have been reported to be overrepresented in obese Caucasian population. The association of these genes polymorphisms with the obesity phenotype in a multiethnic group such as the Brazilian population has not been previously reported.

Methods: To assess the putative contribution of both FTO and UCP-1 to body mass index (BMI) and cardiovascular risk we genotyped SNPs rs9939609 (FTO) and rs6536991, rs22705565 and rs12502572 (UCP-1) from 126 morbidly obese subjects (BMI $42.9 \pm 5.6 \mathrm{~kg} / \mathrm{m}^{2}$, mean $\pm \mathrm{SE}$ ) and 113 normal-weight ethnically matched controls (BMI $22.6 \pm$ $3.5 \mathrm{~kg} / \mathrm{m}^{2}$, mean $\pm \mathrm{SE}$ ). Waist circumference, blood pressure, glucose and serum lipids were also measured. Each sample was also genotyped for 40 biallelic short insertion/deletion polymorphism (indels) for ethnic assignment and to estimate the proportion of European, African and Amerindian biogeographical ancestry in the Brazilian population.

Results: Cases did not differ from controls in the proportions of genomic ancestry. The FTO SNP rs9939609 and UCP-1 SNP rs6536991 were significantly associated with BMI ( $p=0.04$ and $p<0.0001$ respectively). An allele dose dependent tendency was observed for BMI for rs6536991 sample of controls. No other significant associations between any SNP and hypertension, hyperlipidemia and diabetes were noted after correction for BMI and no significant synergistic effect between FTO and UCP-1 SNPs with obesity were noted. There was not an association between rs9939609 (FTO) and rs6536991 (UCP-1) in with maximum weight loss after 1 year in 94 obese patients who underwent bariatric surgery.
\end{abstract}

Conclusion: Our data are consistent with FTO rs9939609 and UCP-1 rs6536991 common variants as contributors to obesity in the Brazilian population.

Keywords: FTO, UCP-1, Morbid obesity, Brazilian population, Multiethnic sample

\section{Background}

Obesity, defined by the World Health Organization (WHO) as body mass index (BMI) above $30 \mathrm{~kg} / \mathrm{m}^{2}$ is an increasingly important clinical and public health challenge in both developed and developing countries and is associated with several co morbidities such as type 2 diabetes, hypertension, cardiovascular diseases and

\footnotetext{
* Correspondence: Idemarco@ufmg.br

'Department of Surgery, School of Medicine, Universidade Federal de Minas Gerais, Av. Alfredo Balena 190, Belo Horizonte 30130-100, Brazil

Full list of author information is available at the end of the article
}

metabolic syndrome [1,2]. More than 400 million adults were obese in 2005, with more than 700 million adults predicted to be obese by 2015 [2]. Although obesity is largely attributed to an imbalance between energy intake and expenditure multiple lines of evidence such as twin and adoption studies [3,4] are consistent with obesity having a contributing genetic component. Thus, in all likelihood obesity is a multifactorial condition due to complex interactions between environmental and genetic factors $[2,5,6]$.

While genes play a role in determining obesity trait, the identification of the genes involved remains elusive

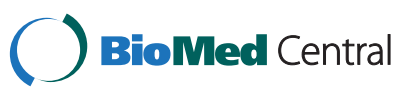


for the most part [6,7]. Three independent genomewide (GWAS) studies reported significant association between obesity (determined by BMI) and common genetic variants in the fat mass and obesity-associated (FTO) gene including the SNP rs9939609 [8-10]. This association was also replicated in genetically heterogeneous populations of Caucasians and Asians [11-14], but discordant results have been observed in African populations [15-17]. Furthermore, the differences in risk allele frequencies and linkage disequilibrium structure across ethnicities can provide further insights to refine the association signal and identify the true risk variant.

Of particular interest is the fact that the FTO variants do not seem to affect BMI or the risk of obesity in African American [9,15], Chinese Hans [18] or Oceanic populations [19]. The minor allele frequency in these populations is less than half of that reported for populations of European descent and the patterns of linkage disequilibrium are also distinct.

In addition, many association studies were also performed in various populations to elucidate the potential contribution of $U C P-1$ polymorphisms to various obesity phenotypes [20,21]. Uncoupling protein 1 (UCP1) is abundant in brown adipose tissue, and dissipates energy through heat. Energy expenditure is a complex trait comprising metabolic rate at rest, and physical activity, diet-induced and adaptive thermogenesis [22]. The contribution of the thermoregulatory mechanisms to body weight regulation appears to be critical in homeothermic animals [23]. As such $U C P-1$ is candidate gene for obesity [24-26].

The association of both FTO and UCP-1 polymorphisms with the obesity phenotype in the Brazilian population has not been reported, and that was the aim of the present study.

\section{Methods \\ Participants}

We recruited 126 obese patients with mean BMI of $42.9 \pm$ $5.6 \mathrm{~kg} / \mathrm{m}^{2}$, mean $\pm \mathrm{SE}$ ) from the Bariatric Surgical Clinics of Hospital Felicio Rocho and 113 non-obese controls from General Endocrine Clinic (Hospital Felício Rocho) with mean BMI of $22.6 \pm 3.5 \mathrm{~kg} / \mathrm{m}^{2}$, mean $\pm \mathrm{SE}$ ). Obesity was defined as BMI $\geq 30 \mathrm{~kg} / \mathrm{m}^{2}$ and non-obese was defined as BMI $<30 \mathrm{~kg} / \mathrm{m}^{2}$. Height and weight were measured with participants dressed in lightweight clothing without shoes. Waist circumference, blood pressure, glucose and serum lipids were also measured. Waist circumference, blood pressure, glucose and serum lipids were also measured. All patients were followed up by the staff of these clinics and data on medication use and diagnosis were considered for enrollment in the study as well as to define disease status.
We genotyped one SNP of the FTO gene and three of the $U C P-1$ gene. The weight of 94 obese patients was obtained one year after bariatric surgery. All participants signed a written informed consent, and the study was approved by the Ethics Committee of the Universidade Federal de Minas Gerais.

\section{Genotyping}

Genomic DNA extraction was performed from whole blood using a standard protocol. The FTO rs9939609 and UCP-1 rs6536991, rs2270565 and rs12502572 were genotyped by allelic discrimination Taqman assays (Applied Biosystems, Foster City, CA). PCR was performed in 96-well format in a total of $10 \mu$ l reaction volume using 10ng of genomic DNA and FAM/VIC dye labeled allelic probes with the Taqman Universal Fast Master mix and subjected to $95^{\circ} \mathrm{C}$ for $15 \mathrm{~min}$, and $40-50$ cycles of $95^{\circ} \mathrm{C}$ for $15 \mathrm{sec}$ and $60^{\circ} \mathrm{C}$ for 45 seconds on an $\mathrm{ABI}$ 9800 Fast Thermocycler (Applied Biosystems, Foster City, CA). The Taqman assay plates were transferred to ABI 7500 Fast Real Time PCR system in which the fluorescence intensity in each well of the plate was recorded and genotypes were analyzed using Sequence Detection Software 1.3. Genotyping quality control procedures included genotyping $10 \%$ duplicates for accuracy checking and inclusion of both positive and nontemplate controls in each 96-well plate. Genotyping success rate was $99.5 \%$. Genotyping accuracy as determined by concordance between duplicates was $100 \%$.

In addition, each sample was independently typed for 40 biallelic short insertion/deletion polymorphisms (indels) to establish the ancestry of our studied sample [27].

\section{Statistical analyses}

Allele and genotype frequencies were compared between case and control groups with the $\mathrm{X}^{2}$ test using the Unphased software program v.3.0.13. Deviation of allele frequency from Hardy-Weinberg equilibrium (HWE) was tested for all SNPs using the Haploview software. In addition, linkage disequilibrium (LD) pattern between the three studied SNPs near the UCP-1 was tested also using Haploview. One thousand permutation tests were done for the SNPs near the UCP-1. We performed 1,000 permutations in each test to estimate the global significance of the results for all analyses and to validate the expectation-maximization values. $\mathrm{Pu}$ tative associations with the FTO and UCP-1 loci, including suitable adjustment for age, were assessed via regression analysis. In table 1 , the $\mathrm{p}$-value was calculated using Mann-Whitney $U$ test to compare continuous variables, and chi-square analysis was performed to compare categorical variables. We used the Structure software to estimate the proportion of European, African 
Table 1 Clinical characterization of obese and control subjects*

\begin{tabular}{lccc}
\hline $\begin{array}{l}\text { Anthropometric } \\
\text { measure }\end{array}$ & $\begin{array}{c}\text { Obese } \\
(\mathbf{n}=\mathbf{1 2 6})\end{array}$ & $\begin{array}{c}\text { Control } \\
(\mathbf{n}=\mathbf{1 1 3})\end{array}$ & $\boldsymbol{P}$ value \\
\hline Age & $40.3 \pm 12.7$ & $50.0 \pm 17.3$ & $<0.0001$ \\
Gender (M/F) & $21 / 105$ & $20 / 93$ & 0.355 \\
Height (m) & $1.63 \pm 0.09$ & $1.60 \pm 0.09$ & 0.038 \\
Weight (kg) & $115.0 \pm 21.4$ & $58.3 \pm 10.4$ & $<0.0001$ \\
BMl & $42.9 \pm 5.6$ & $22.6 \pm 3.5$ & $<0.0001$ \\
Waist circumference (cm) & $119 \pm 13$ & $79 \pm 12$ & $<0.0001$ \\
Dislipidemia (\%) & 54.9 & 46 & 0.631 \\
HDL (mg/dl) & $51 \pm 12$ & $47 \pm 15$ & 0.0248 \\
LDL (mg/dl) & $121 \pm 35$ & $125 \pm 34$ & 0.3355 \\
Triglycerides (mg/dl) & $151 \pm 91$ & $134 \pm 65$ & 0.3075 \\
Diabetes (\%) & 17.2 & 11.4 & $<0.0001$ \\
Glucose (mg/dl) & $105 \pm 42$ & $89 \pm 21$ & $<0.0001$ \\
Hypertension (\%) & 40.9 & 21.2 & 0.005 \\
Systolic blood pressure (mmHg) & $136 \pm 14$ & $131 \pm 18$ & 0.0016 \\
Diastolic blood pressure (mmHg) & $87 \pm 9$ & $82 \pm 9$ & $<0.0001$ \\
\hline
\end{tabular}

*Mann-Whitney $U$ test and chi-square analysis.

and Amerindian biogeographical ancestry of each group and the Unphased software to analyze the polymorphisms and their association with obesity, diabetes, lipids, hypertension and metabolic syndrome. Nonparametric analysis was performed by the GraphPad Prism 5 to analyze a significant synergistic effect between $F T O$ and UCP-1 SNPs with obesity. Difference in BMI between genotypes was analyzed using a multiple linear regression, with BMI as the dependent variable and genotype as the independent variable, and with gender as covariate for BMI. Statistical significance was taken at a $p$-value $<0.05$ for all comparisons.

\section{Results}

Clinical characteristics of the 239 participants in this study are shown in Table 1 . The study sample consisted of 239 Brazilian individuals, aged 18-72 years old. Patients were 126 severely obese subjects (BMI $42.9 \pm 5.6 \mathrm{~kg} / \mathrm{m}^{2}$ ) with a mean age of $40.3 \pm 12.7$ years (mean \pm SE) (range 18-71 years). Controls were 113 normal-weight (or somewhat overweight) subjects (BMI $22.6 \pm 3.5 \mathrm{~kg} / \mathrm{m}^{2}$ ) with a mean age of $50.0 \pm 17.3$ years old (mean \pm SE) (range 18-72 years).

Genotyping was performed for one FTO SNP (rs9939609) and for three UCP-1 SNPs (rs6536991, rs2270565 and rs12502572). All SNPs were in HardyWeinberg equilibrium ( $P$-value $0.88,0.12,0.35$ and 0.49 for rs9939609, rs6536991, rs2270565 and rs12502572 respectively). Table 2 shows the position and HardyWeinberg equilibrium of SNPs. The calculated power estimate for the rs2270565 and rs12502572 was 49.4\% and $61.0 \%$, respectively.

The minor allele frequencies (MAFs) observed in this study $(0.435,0.383,0.056$ and 0.480 for rs9939609, rs6536991, rs2270565 and rs12502572, respectively) were close to those in dbSNP (http://www.ncbi.nlm.nih. gov/snp) population $(0.355,0.319,0.073$ and 0.467 , respectively).

As shown in Table 3, the FTO SNP rs9939609 and UCP-1 SNP rs6536991 demonstrated a statistically significant association with the obesity phenotype as measured by BMI $(\mathrm{p}=0.04$ and $\mathrm{p}<0.0001$ respectively). However two UCP-1 SNPs rs2270565 and rs12502572 were not associated with the obesity phenotype $(\mathrm{p}=0.25$ and $\mathrm{p}=0.35$ respectively). An allele dose-dependent tendency was observed for BMI just for rs6536991 sample of controls (Figure 1). Pairwise LD demonstrated one LD block in the UCP-1 gene comprising two SNPs (rs2270565 and 12502572, D $=1.0$, LOD 5.29, r-squared 0.082). There was also a moderate LD in UCP-1 rs6536991 and rs12502572 polymorphisms $\left(D_{-}=0.781\right.$, LOD 37.81, r-squared 0.525) as well as between the polymorphisms rs6536991 and rs2270565 $\left(D_{-}=0.637\right.$, LOD 0.6, r-squared 0.015).Clinical characteristics of the studied population by FTO rs9939609 and UCP-1 rs6536991 genotypes are shown in Tables 4 and 5, respectively.

There was a seemingly statistically significant association between rs6536991 with diabetes $(\mathrm{p}=0.01)$, rs6536991 with hypertension ( $\mathrm{p}=0.003$ ) and $\mathrm{rs6536991}$ with dyslipidemia $(\mathrm{p}=0.035)$ which disappeared after BMI stratification. A borderline association between rs9939609 with diabetes $(\mathrm{p}=0.05)$ also disappeared after BMI stratification. We did not find a significant synergistic effect between FTO and UCP-1 SNPs with obesity.

Table 2 Position and Hardy-Weinberg equilibrium of SNPs

\begin{tabular}{|c|c|c|c|c|c|c|}
\hline SNP name & Chromosome & $\begin{array}{l}\text { Chromosome } \\
\text { position }\end{array}$ & Gene & SNP Type & $\begin{array}{l}\text { Ancestral } \\
\text { allele }\end{array}$ & $\begin{array}{l}\text { Hardy-Weinberg } \\
\text { p value }\end{array}$ \\
\hline rs6536991* & 4 & 141481581 & UCP1 & Intron & C & 0.12 \\
\hline$r s 2270565$ & 4 & 141483471 & UCP1 & Missense mutation & $\mathrm{T}$ & 0.35 \\
\hline rs 12502572 & 4 & 141485134 & UCP1 & Intron & $A$ & 0.49 \\
\hline rs9939609 & 16 & 53820686 & FTO & Intron & A & 0.88 \\
\hline
\end{tabular}

${ }^{*}$ tag SNPs; ${ }^{* *}$ HWpval: HWE $P$ value'. $X^{2}$ tests. 
Table 3 Association between FTO (rs9939609), UCP-1 (rs6536991, rs2270565 and rs12502572) with obesity and HardyWeinberg equilibrium (HWE)

\begin{tabular}{|c|c|c|c|c|c|c|c|c|}
\hline \multirow[t]{2}{*}{ Genotype } & \multicolumn{2}{|c|}{ Patients } & \multicolumn{2}{|c|}{ Controls } & \multirow[t]{2}{*}{$P$} & \multirow[t]{2}{*}{ OR } & \multirow[t]{2}{*}{$95 \% \mathrm{Cl}$} & \multirow[t]{2}{*}{ HWE } \\
\hline & $n$ & $\%$ & $\mathrm{n}$ & $\%$ & & & & \\
\hline \multicolumn{9}{|l|}{ rs 9939609} \\
\hline Tा & 34 & 27 & 41 & 36 & 0.04 & 1 & - & 0.88 \\
\hline TA & 60 & 48 & 57 & 50 & & 1.27 & $0.71-2.27$ & \\
\hline AA & 32 & 25 & 15 & 13 & & 2.57 & $1.2-3.52$ & \\
\hline \multicolumn{9}{|l|}{ Allele } \\
\hline $\mathrm{T}$ & 128 & 51 & 139 & 62 & 0.02 & 1 & - & \\
\hline A & 124 & 49 & 87 & 38 & & 1.55 & $1.07-2.23$ & \\
\hline \multicolumn{9}{|l|}{ rs6536991 } \\
\hline$\Pi T$ & 10 & 8 & 17 & 15 & $<0.0001$ & 1 & - & 0.12 \\
\hline TC & 87 & 69 & 42 & 37 & & 3.52 & $1.48-8.35$ & \\
\hline CC & 29 & 23 & 54 & 48 & & 0.91 & $0.37-2.25$ & \\
\hline \multicolumn{9}{|l|}{ Allele } \\
\hline $\mathrm{T}$ & 107 & 42 & 76 & 34 & 0.046 & 1 & - & \\
\hline C & 145 & 58 & 150 & 66 & & 0.69 & $0.47-1.0$ & \\
\hline \multicolumn{9}{|l|}{ rs2270565 } \\
\hline$\Pi$ & 109 & 87 & 104 & 92 & 0.25 & 1 & - & 0.35 \\
\hline TA & 16 & 13 & 9 & 8 & & 1.70 & $0.72-4.01$ & \\
\hline AA & 1 & 1 & 0 & 0 & & $2.968 \mathrm{e}+{ }^{007}$ & $1109 e++^{007}-7943 e+{ }^{007}$ & \\
\hline \multicolumn{9}{|l|}{ Allele } \\
\hline $\mathrm{T}$ & 23493 & 21796 & 0.13 & 1 & - & & & \\
\hline A & 187 & 94 & & 1.86 & $0.82-4.21$ & & & \\
\hline \multicolumn{9}{|l|}{ rs12502572 } \\
\hline GG & 4032 & 4641 & 0.35 & 1 & - & 0.49 & & \\
\hline GA & 6148 & 4742 & & 1.49 & $0.84-2.64$ & & & \\
\hline AA & 2520 & 2018 & & 1.44 & $0.70-2.97$ & & & \\
\hline \multicolumn{9}{|l|}{ Allele } \\
\hline G & 14156 & 13962 & 0.22 & 1 & - & & & \\
\hline$A$ & 11144 & 8738 & & 1.26 & $0.87-1.81$ & & & \\
\hline
\end{tabular}

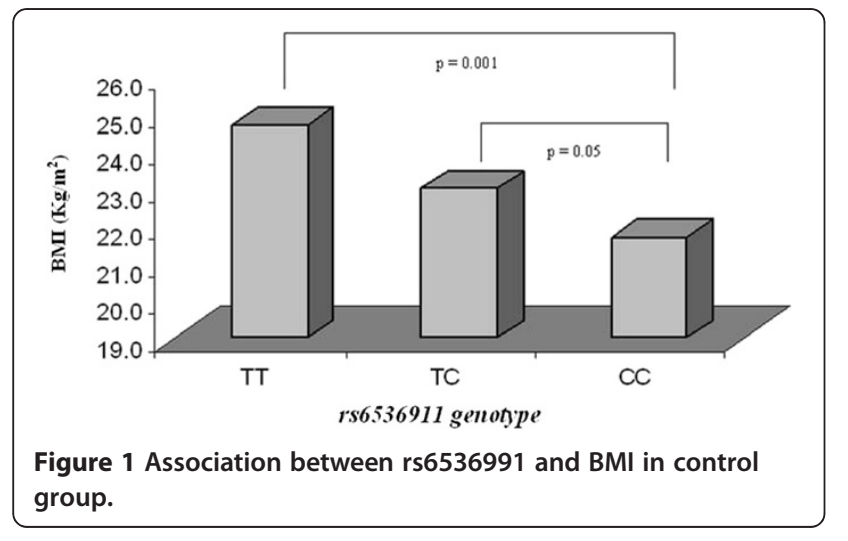

Difference in BMI between genotypes was analyzed using a multiple linear regression and confirmed the association between FTO rs9939609 ( $\mathrm{p}=0.0420)$ and UCP-1 rs6536991 ( $\mathrm{p}<0.001)$ genotypes with BMI.

There was not an association between rs9939609 (FTO) and rs6536911 (UCP-1) with maximum weight loss in 94 obese patients one year after bariatric surgery $(\mathrm{p}=0.410$ and $\mathrm{p}=0.394$ respectively).

Using genotyping data for 40 polymorphic indel loci, which form a powerful ancestry informative test battery (27) the proportion of Europeans, Africans and Amerindians were $0.872 \pm 0.021,0.087 \pm 0.017$ and $0.039 \pm$ 0.092 (mean $\pm \mathrm{SE}$ ), respectively for the cases and $0.928 \pm$ $0.012,0.037 \pm 0.006$ and $0.033 \pm 0.061$, respectively 
Table 4 Clinical and laboratory data ${ }^{a}$ (FTO rs9939609 genotype)

\begin{tabular}{|c|c|c|c|c|c|c|c|c|c|c|c|}
\hline & $\begin{array}{l}\text { Age } \\
\text { (years) }\end{array}$ & $\begin{array}{l}\text { Weight } \\
(\mathrm{Kg})\end{array}$ & $\begin{array}{l}\text { Height } \\
(\mathrm{cm})\end{array}$ & $\begin{array}{l}\text { Waist } \\
(\mathrm{cm})\end{array}$ & $\begin{array}{l}\mathrm{b}_{\mathrm{BMI}} \\
\left(\mathrm{kg} / \mathrm{m}^{2}\right)\end{array}$ & $\begin{array}{l}{ }^{c} \mathrm{HDL} \\
(\mathrm{mg} / \mathrm{dl})\end{array}$ & $\begin{array}{l}{ }^{d} \mathrm{LDL} \\
(\mathrm{mg} / \mathrm{dl})\end{array}$ & $\begin{array}{l}{ }^{\text {eTG }} \\
\text { (mg/dl) }\end{array}$ & $\begin{array}{l}\text { fSBP } \\
(\mathrm{mmHg})\end{array}$ & $\begin{array}{l}{ }^{9} \mathrm{DBP} \\
(\mathrm{mmHg})\end{array}$ & $\begin{array}{l}\text { Fasting Glucose } \\
\text { (mg/dl) }\end{array}$ \\
\hline \multicolumn{12}{|c|}{ Obese } \\
\hline \multirow[t]{2}{*}{$\pi$} & $37.7 \pm 13.3$ & $115.8 \pm 25.2$ & $163.3 \pm 10.2$ & $116.5 \pm 14.2$ & $43.1 \pm 6$ & $52.8 \pm 16.1$ & $126.2 \pm 33.9$ & $149.9 \pm 101.2$ & $137.1 \pm 14.7$ & $86.2 \pm 7.3$ & $109.9 \pm 58.8$ \\
\hline & $(33.1-42.4)$ & $(107-124.6)$ & (159.7-166.8) & $(111.4-121.5)$ & $(41-45.1)$ & $(46.9-58.6)$ & $(114-138.5)$ & $(113.5-186.4)$ & $(131.9-142.2)$ & $(83.6-88.7)$ & $(88.7-131.1)$ \\
\hline \multirow[t]{2}{*}{ TA } & $42.6 \pm 12.6$ & $115.8 \pm 19.4$ & $163.2 \pm 8$ & $122.0 \pm 12.8$ & $43.3 \pm 5.7$ & $51.1 \pm 10.9$ & $126.2 \pm 34$ & $161.0 \pm 98.7$ & $135.2 \pm 13.9$ & $86.3 \pm 8.9$ & $105.4 \pm 40.3$ \\
\hline & $(39.8-45.7)$ & $(110.8-120.8)$ & $(161.1-165.3)$ & $(118.6-125.4)$ & $(41.9-44.8)$ & $(48.2-54)$ & $(117.1-135.3)$ & $(134.8-187.2)$ & $(131.6-138.8)$ & (84-88.6) & $(94.7-116.1)$ \\
\hline \multirow[t]{2}{*}{ AA } & $38.8 \pm 12.1$ & $112.7 \pm 21.2$ & $163.8 \pm 9.2$ & $117.4 \pm 12.3$ & $41.8 \pm 4.8$ & $49.8 \pm 10.1$ & $107.6 \pm 33.4$ & $134.3 \pm 59.9$ & $136.3 \pm 13.4$ & $87.3 \pm 9.5$ & $99.0 \pm 20$ \\
\hline & $(34.4-43.2)$ & $(105.1-120.4)$ & $(160.5-167.2)$ & (112.9-121.8) & $(40-43.5)$ & $(46.1-53.4)$ & $(95.6-119.7)$ & $(112.7-155.9)$ & $(131.4-141.1)$ & (83.9-90.7) & (91.8-106.3) \\
\hline \multicolumn{12}{|c|}{ Control } \\
\hline \multirow[t]{2}{*}{ Tा } & $53.3 \pm 17.6$ & $56.4 \pm 10.7$ & $160.3 \pm 8.9$ & $77.4 \pm 11.1$ & $21.9 \pm 3.4$ & $46.0 \pm 12.3$ & $119.3 \pm 33.9$ & $143.9 \pm 63.9$ & $130.0 \pm 18.5$ & $80.4 \pm 9.6$ & $91.1 \pm 28.1$ \\
\hline & $(47.8-58.9)$ & (53-59.8) & $(157.5-163.1)$ & (73.3-81.4) & $(20.8-22.9)$ & $(41.7-50.4)$ & $(107.3-131.3)$ & $(121.2-166.5)$ & $(124.2-135.9)$ & $(77.4-83.4)$ & (81.3-100.9) \\
\hline \multirow[t]{2}{*}{ TA } & $49.8 \pm 15.8$ & $60.2 \pm 11$ & $160.2 \pm 8.2$ & $81.7 \pm 12.4$ & $23.4 \pm 3.7$ & $48.4 \pm 16.1$ & $129.4 \pm 33.3$ & $124.5 \pm 66.9$ & $131.8 \pm 18$ & $81.9 \pm 8.8$ & $85.1 \pm 13.9$ \\
\hline & $(45.6-54.0)$ & $(57.2-63)$ & $(158.1-162.4)$ & (77.9-85.6) & $(22.4-24.4)$ & $(43.4-53.5)$ & (119-139.8) & $(103.6-145.3)$ & (127.11-136.6) & $(70.6-84.3)$ & (80.8-89.4) \\
\hline \multirow[t]{2}{*}{ AA } & $41.7 \pm 20.2$ & $56.0 \pm 5.3$ & $160.6 \pm 10.8$ & $72.6 \pm 10.4$ & $21.8 \pm 2.1$ & $45.9 \pm 17.9$ & $126.8 \pm 35.4$ & $136.4 \pm 64.3$ & $130.3 \pm 15.1$ & $82.9 \pm 6.5$ & $93.0 \pm 18$ \\
\hline & $(30.5-52.9)$ & $(53-58.9)$ & (154.6-166.5) & $(66-79.2)$ & $(20.6-23)$ & $(35.1-56.7)$ & $(105.4-148.2)$ & $(97.5-175.3)$ & $(121.9-138.6)$ & (79.3-86.6) & (82.6-103.4) \\
\hline
\end{tabular}

${ }^{a}$ Data shown as average \pm SD and 95\% confidence interval of the mean; ${ }^{\mathrm{b}} \mathrm{BMI}$, Body Mass Index; ${ }^{\mathrm{c} H i g h}$ Density Lipoprotein; ${ }^{\mathrm{d} L D L}$, Low Density Lipoprotein; ${ }^{\mathrm{e} T G}$, Triglycerides; ${ }^{\mathrm{f}} \mathrm{SBP}$, Systolic Blood Pressure; ${ }^{9} \mathrm{DBP}$, Diastolic Blood Pressure. TT denotes homozygous carriers of the T allele, TA heterozygous carriers, and AA noncarriers of FTO. 
Table 5 Clinical and laboratory data ${ }^{\mathrm{a}}$ (UCP-1 rs6536991 genotype)

\begin{tabular}{|c|c|c|c|c|c|c|c|c|c|c|c|}
\hline & $\begin{array}{l}\text { Age } \\
\text { (years) }\end{array}$ & $\begin{array}{l}\text { Weight } \\
\text { (Kg) }\end{array}$ & $\begin{array}{l}\text { Height } \\
\text { (cm) }\end{array}$ & $\begin{array}{l}\text { Waist } \\
(\mathrm{cm})\end{array}$ & $\begin{array}{l}\mathrm{BMI} \\
\left(\mathrm{kg} / \mathrm{m}^{2}\right)\end{array}$ & $\begin{array}{l}\mathrm{HDL} \\
(\mathrm{mg} / \mathrm{dl})\end{array}$ & $\begin{array}{l}\text { LDL } \\
(\mathrm{mg} / \mathrm{dl})\end{array}$ & $\begin{array}{l}\text { TG } \\
(\mathrm{mg} / \mathrm{dl})\end{array}$ & $\begin{array}{l}\text { SBP } \\
(\mathrm{mmHg})\end{array}$ & $\begin{array}{l}\text { DBP } \\
(\mathrm{mmHg})\end{array}$ & $\begin{array}{l}\text { Fasting Glucose } \\
(\mathrm{mg} / \mathrm{dl})\end{array}$ \\
\hline \multicolumn{12}{|c|}{ Obese } \\
\hline \multirow[t]{2}{*}{$\pi$} & $40.5 \pm 9.5$ & $124.2 \pm 29.4$ & $164.3 \pm 10.1$ & $124.6 \pm 17.5$ & $45.6 \pm 7.8$ & $47.2 \pm 6.2$ & $113.1 \pm 30.1$ & $142.1 \pm 48.1$ & $131 \pm 8.7$ & $83.5 \pm 6.7$ & $98.5 \pm 15.8$ \\
\hline & $(33.7-47.3)$ & $(103.2-145.2)$ & $(157.1-171.5)$ & $(112.1-137.1)$ & $(40-51.2)$ & $(42.7-51.7)$ & (91.6-134.6) & $(107.7-176.5)$ & (124.7-137.3) & (78.7-88.3) & (87.2-109.8) \\
\hline \multirow[t]{2}{*}{ TC } & $39.8 \pm 12.6$ & $114.6 \pm 20.9$ & $163.6 \pm 8.8$ & $119.7 \pm 12$ & $42.6 \pm 5.8$ & $50.6 \pm 13.2$ & $119.6 \pm 35.7$ & $154.0 \pm 96.7$ & $137.4 \pm 14.1$ & $87.2 \pm 8.7$ & $107.7 \pm 48.6$ \\
\hline & $(37.1-42.5)$ & $(110.2-119.1)$ & $(161.8-165.5)$ & $(117.1-122.3)$ & $(41.4-43.8)$ & $(47.8-53.5)$ & $(111.8-127.4)$ & $(132.8-175.1)$ & $(134.4-140.4)$ & (85.3-89) & $(97.1-118.3)$ \\
\hline \multirow[t]{2}{*}{ CC } & $41.9 \pm 14.2$ & $113.0 \pm 20$ & $162.4 \pm 8.9$ & $116.5 \pm 14.7$ & $42.7 \pm 4.7$ & $54.4 \pm 10.7$ & $129.3 \pm 32.1$ & $145.4 \pm 85.7$ & $133.4 \pm 14.5$ & $85.7 \pm 8.9$ & $98.9 \pm 23.2$ \\
\hline & $(36.5-47.3)$ & (105.4-120.6) & $(159-165.8)$ & $(111-122.1)$ & $(40.9-44.5)$ & $(50.1-58.6)$ & $(116.6-142)$ & $(112.2-178.7)$ & (127.9-138.9) & $(82.3-89.1)$ & (89.9-107.9) \\
\hline \multicolumn{12}{|c|}{ Control } \\
\hline \multirow[t]{2}{*}{$\pi$} & $51.2 \pm 16.3$ & $64.0 \pm 9.7$ & $161.0 \pm 6.1$ & $85.8 \pm 11.2$ & $24.7 \pm 3.4$ & $54.8 \pm 15$ & $134.1 \pm 39.1$ & $127.5 \pm 52.4$ & $135.7 \pm 21.7$ & $81.6 \pm 6.3$ & $80.0 \pm 12.6$ \\
\hline & $(42.9-59.6)$ & (59-69) & $(157.8-164.2)$ & (78.6-93) & (22.9-26.4) & $(46.1-63.5)$ & (111.5-156.7) & $(97.2-157.8)$ & (124.5-146.9) & (78.4-84.9) & $(72.7-87.2)$ \\
\hline \multirow[t]{2}{*}{$\mathrm{TC}$} & $52.1 \pm 15$ & $58.0 \pm 9.7$ & $158.4 \pm 8$ & $81.2 \pm 17.8$ & $23.0 \pm 3.1$ & $42.3 \pm 11.4$ & $133.4 \pm 35.8$ & $157.6 \pm 67.7$ & $134.2 \pm 17.8$ & $83.3 \pm 9.2$ & $91.1 \pm 27.3$ \\
\hline & $(47.5-56.8)$ & $(55-61.1)$ & $(155.9-160.9)$ & $(77.5-84.9)$ & $(22.1-24)$ & $(38.3-46.2)$ & $(121.6-145.2)$ & (135.3-179.8) & (128.7-139.8) & $(80.4-86.2)$ & $(82.1-100.1)$ \\
\hline \multirow[t]{2}{*}{ CC } & $48.0 \pm 19.3$ & $56.6 \pm 10.7$ & $161.6 \pm 9.8$ & $74.4 \pm 11.6$ & $21.7 \pm 3.5$ & $49.3 \pm 16.4$ & $113.1 \pm 25.6$ & $110.4 \pm 59.5$ & $126.9 \pm 15.7$ & $80.1 \pm 9.1$ & $89.3 \pm 14.9$ \\
\hline & $(42.7-53.3)$ & (53.7-59.5) & (158.9-164.2) & (70.6-78.2) & (20.7-22.6) & $(43.8-54.9)$ & (104.4-121.8) & (90.3-130.5) & $(112.7-131.2)$ & (77.6-82.6) & (84.4-94.2) \\
\hline
\end{tabular}

${ }^{a}$ Data shown as average \pm SD and 95\% confidence interval of the mean; ${ }^{\mathrm{b}} \mathrm{BMI}$, Body Mass Index; ${ }^{\mathrm{C} H i g h}$ Density Lipoprotein; ${ }^{\mathrm{d} L D L}$, Low Density Lipoprotein; ${ }^{\mathrm{e} T G}$, Triglycerides; ${ }^{\mathrm{f}} \mathrm{SBP}$, Systolic Blood Pressure; ${ }^{9} \mathrm{DBP}$, Diastolic Blood Pressure. TT denotes homozygous carriers of the T allele, TC heterozygous carriers, and CC noncarriers of UCP-1 rs6536991. 
for the controls. The differences in the proportions of genomic ancestries between the two groups were not statistically significant $(\mathrm{p}=0.822, \mathrm{p}=0.312$ and $\mathrm{p}=0.324$, respectively).

\section{Discussion}

Gene variants have been reported in association with obesity or obesity-related phenotypes. However, lack of replication has long been a big challenge in these genetic association studies [28]. The association of the FTO gene with human obesity is robust in populations of European descendent [8-10]. To date, negative results have involved non-European populations [13,14,16-19]. Although the genetic architecture of the FTO locus has not been examined in great detail in these populations evidence is emerging that rs9939609 might be in tight linkage disequilibrium with a casual variant in populations of European descendent. However, this linkage disequilibrium may break down in other ethnic and racial groups suggesting that these population have differences arisen through evolutionary divergence, perhaps as a result of some negative selection pressure against the FTO risk alleles in some African and East Asian population [12-18].

Interestingly, the study by Frayling et al. (2007) [8] identified FTO through a genome-wide association study for type 2 diabetes. After adjusting for BMI, the association with type 2 diabetes was completely abolished, suggesting that the FTO-type 2 diabetes association was mediated through BMI. Subsequently, the association with BMI and obesity was unequivocally replicated in 13 cohorts comprising more the 38000 individuals [29]. The effect of FTO SNPs on BMI is modest, with those individuals homozygous for the risk allele weighting, on average, $3 \mathrm{~kg}$ more than those homozygous for the protective allele [8]. However, physical activity can attenuate this FTO association [30]. BMI-associated SNPs lie within a 47 kilobase (kb) linkage disequilibrium (LD) block encompassing parts of the first two introns as well as exon 2 of the FTO gene. Thus, the association signal could be due to correlation between FTO intronic SNPs and variation elsewhere in the gene or control elements of other genes [8]. The precise mechanism by which the FTO gene leads to obesity development is unclear [31]. The FTO gene encodes a 2-oxoglutarate-dependent nucleic acid demethylase that is present in many tissues and is most abundant in the hypothalamus where the control center of energy balance lie [8,31]. Studies in mice showing that Fto mRNA levels are regulated by feeding and fasting have provided a mechanistic link between FTO and body weight and energy homeostasis [31]. Cecil et al. (2008) [32] demonstrated that a predisposition to obesity does not appear to be involved in the regulation of expenditure but may have a role in the control of food intake and food choice, suggesting a link to a hyperphagic phenotype or a preference for energydense foods.

In this report we confirmed the association of the FTO variant with BMI in a population of Brazilians with multi-ethnic ancestry. The obese population who was homozygous for the risk allele weighted $3.1 \mathrm{~kg}$ and $1.3 \mathrm{~kg} / \mathrm{m}^{2}$ more than those homozygous for the protective allele as demonstrated by Frayling et al. (2007) [8]. We did not find evidence of association with type 2 diabetes or most of the obesity-related phenotypes in quantitative trait analyses mainly after stratification for BMI as also demonstrated by Frayling et al. (2007) [8].

In addition, many studies have looked for many candidate genes to determine genetic factors implicated in the pathogenesis of obesity, related metabolic disorders and diabetes. $U C P-1$, which plays a major role in thermogenesis, was suggested to be one of these candidate genes [33]. Uncoupling protein 1 (UCP1), a $32 \mathrm{kDa}$ protein located in the inner mitochondrial membrane, is abundant in brown adipose tissue (BAT), in which UCP-1 allows to re-enter the matrix, bypassing the ATP synthase. The usually low proton conductance of the membrane is increased, which results in an acceleration of mitochondrial respiration. The dissipation of the proton electrochemical gradient leads to an uncoupled respiration and heat production, the main function of BAT (34). UCP-1 expression is strongly induced when thermogenesis is required [34]. UCP1 has been reported to play an important role in thermogenesis and energy expenditure and is implicated in the pathogenesis of obesity and metabolic disorders in human [35-37]. The influence of the polymorphism of $U C P-1$ gene on obesity had been reported in some studies [20,21] while others found no association [38-40].

In our study we investigated the effect of $U C P-1$ gene SNPs on obesity and obesity related phenotypes among Brazilian people. Our findings show a significant association between the minor allele rs6536991 but not on rs2270565 and rs12502572 with obesity. Again, after BMI stratification, the correlation between rs6536991 and type 2 diabetes, hypertension and dislipidemia disappeared. Interestingly, the effect of the rs6536991 was greater than the effect of FTO rs9939609 in our population, with those individuals homozygous for the risk allele weighting were on average, $3 \mathrm{~kg} / \mathrm{m}^{2}$ of BMI more than those homozygous for the protective allele. Taken together we found evidence that rs9939609 in the FTO and rs6536991 in the UCP-1 gene increased the risk of obesity but not obesity related phenotypes in the Brazilian population studied. The SNPs rs2270565 and rs12502572 from the $U C P-1$ were not correlated with obesity and obesity related phenotype. 
The reasons for the non effect of the SNPs rs2270565 and rs12502572 could be the relatively small sample size we report or because they were not in linkage disequilibrium compared to rs6536991, which showed association, justifying different behaviors between them. Indeed, a sample size of 445 and 350 people, respectively, would be required to ensure an $80 \%$ power. Furthermore, we did not find a significant synergistic effect between FTO and UCP-1 SNPs with BMI and no significant correlation with maximum weight loss one year of bariatric surgery. Further studies examining a larger sample size would be necessary to detect this synergistic effect or this association with weight loss one year after bariatric surgery [41].

Brazilians form a very heterogeneous population, which is the result of five centuries of inter-ethnic crosses between peoples from three continents: the European colonizers mainly represented by the Portuguese, African slaves, and the autochthonous Amerindians. Genomic controls help to rule out alternate explanations regarding the influence of racial and ethnic ancestry on this important health outcome [6]. These three groups have admixed to a point which there is very little correlation between skin color and ancestry [42]. Despite the more representative European ancestry, the differences in the proportions of genomics ancestry between the two groups were not significant. These findings bring interesting remarks on the social and genetic epidemiology of obesity.

Some potential limitations should be considered in our study. First, a limited sample size from a single center albeit representative of our population. Second, interaction between lifestyle, physical activity and genes could be a confounding factor and these were not investigated.

Despite the recent success in identifying obesity gene variants using the genome wide association approach, it is well established that such variants do not cause obesity without the individual being exposed to an obesitypromoting environment. Also, only a small fraction of the genetic contribution to obesity has presently been identified [43]. This could be owing to a complex interplay between genetic and environmental factors masking the effect of specific genetic variants.

\section{Conclusions}

In conclusion we identified two SNPs that were associated with a greater BMI in our population. We believe that further studies are warranted, with a greater number of subjects, to examine whether other common variants in the FTO and $U C P-1$ genes could be synergistic in the increased risk for obesity or obesity related phenotypes in the Brazilian and other multiethnic populations.

\section{Competing interests}

The authors declare no conflict of interest.

\section{Authors' contributions}

AVR and MS recruited subjects and performed laboratory work. LB-R performed laboratory work and data analisis. BAR and LC-V performed laboratory work. LD, EF and DMM conceived and designed the study as well as performed data analysis. All authors read and approved the final manuscript.

\section{Acknowledgements}

The authors thank all individuals for their participation in the study. This study was funded by the grants from the CNPq and FAPEMIG (Brazil).

\section{Author details}

${ }^{1}$ Department of Surgery, School of Medicine, Universidade Federal de Minas Gerais, Av. Alfredo Balena 190, Belo Horizonte 30130-100, Brazil. ${ }^{2}$ Hospital Felício Rocho, Belo Horizonte 30110-068, Brazil. ${ }^{3}$ The Susanne Levy Gertner Oncogenetics Unit, Chaim Sheba Medical Center, Tel-Hashomer 52621, Israel. ${ }^{4}$ Department of Pediatrics, Universidade Federal de Minas Gerais, Belo Horizonte 30130-100, Brazil. ${ }^{5}$ Department of Medicine, Universidade Federal de Minas Gerais, Belo Horizonte 30130-100, Brazil.

Received: 31 May 2012 Accepted: 25 October 2012

Published: 7 November 2012

\section{References}

1. Mokdad AH, Ford ES, Bowman BA, Dietz WH, Vinicor F, Bales VS, Marks JS: Prevalence of obesity, diabetes, and obesity-related health risk factors 2001. JAMA 2003, 289:76-79.

2. World Health Organization: Fact sheet: obesity and overweight. Geneva: World Health Organization; 2006. http://www.who.int/mediacentre/ factsheets/fs311/en/print.html.

3. Maes $\mathrm{HH}$, Neale MC, Eaves LJ: Genetic and environmental factors in relative body weight and human adiposity. Behav Genet 1997, 27:325-351.

4. Wardle J, Carnell S, Haworth CM, Plomin R: Evidence for a strong genetic influence on childhood adiposity despite the force of the obesogenic environment. Am J Clin Nutr 2008, 87:398-404.

5. Boutin P, Froguel P: Genetics of human obesity. Best Pract Res Clin Endocrinol Metab 2001, 15:391-404.

6. Boardman JD, Blalock CL, Corley RP, Stallings MC, Domingue BW, Mcqueen MB, Crowley TJ, Hewitt JK, Lu Y, Field SH: Ethnicity, body mass and genome-wide data. Biodemography Soc Biol 2010, 56:123-136.

7. Saunders $C L$, Chiodini BD, Sham P, Lewis CM, Abkevich V, Adeyemo AA, de Andrade M, Arya R, Berenson GS, Blangero J, Boehnke M, Borecki IB, Chagnon YC, Chen W, Comuzzie AG, Deng HW, Duggirala R, Feitosa MF, Froguel P, Hanson RL, Hebebrand J, Huezo-Dias P, Kissebah AH, Li W, Luke A, Martin LJ, Nash M, Ohman M, Palmer LJ, Peltonen L, et al: Meta-analysis of genoma-wide linkage studies in BMI and obesity. Obesity 2007, 15:2263-2275.

8. Frayling TM, Timpson NJ, Weedon MN, Zeggini E, Freathy RM, Lindgren CM, Perry JR, Elliott KS, Lango H, Rayner NW, Shields B, Harries LW, Barrett JC, Ellard S, Groves CJ, Knight B, Patch AM, Ness AR, Ebrahim S, Lawlor DA, Ring SM, Ben-Shlomo Y, Jarvelin MR, Sovio U, Bennett AJ, Melzer D, Ferrucci L, Loos RJ, Barroso I, Wareham NJ, et al: A common variant in the FTO gene is associated with body mass index and predisposes to childhood and adult obesity. Science 2007, 316:889-894.

9. Scuteri A, Sanna S, Chen WM, Uda M, Albai G, Strait J, Najjar S, Nagaraja R, Orrú M, Usala G, Dei M, Lai S, Maschio A, Busonero F, Mulas A, Ehret GB, Fink AA, Weder AB, Cooper RS, Galan P, Chakravarti A, Schlessinger D, Cao A, Lakatta E, Abecasis GR: Genome-wide association scan shows genetic variants in the FTO gene are associated with obesity-related traits. PLOS Genet 2007, 3:e115.

10. Dina C, Meyre D, Gallina S, Durand E, Körner A, Jacobson P, Carlsson LM, Kiess W, Vatin V, Lecoeur C, Delplanque J, Vaillant E, Pattou F, Ruiz J, Weill J, Levy-Marchal C, Horber F, Potoczna N, Hercberg S, Le Stunff C, Bougnères P, Kovacs P, Marre M, Balkau B, Cauchi S, Chèvre JC, Froguel P: Variation in FTO contributes to childhood obesity and severe adult obesity. Nat Genet 2007, 39:724-726.

11. Chang YC, Liu PH, Lee WJ, Chang TJ, Jiang YD, Li HY, Kuo SS, Lee KC, Chuang LM: Common variation in the fat mass and obesity-associated 
(FTO) gene confers risk of obesity and modulates BMI in the Chinese population. Diabetes 2008, 57:2245-2252.

12. Grant SF, Li M, Bradfield JP, Kim CE, Annaiah K, Santa E, Glessner JT, Casalunovo T, Frackelton EC, Otieno FG, Shaner JL, Smith RM, Imielinski M, Eckert AW, Chiavacci RM, Berkowitz RI, Hakonarson H: Association analysis of the FTO gene with obesity in children of Caucasian and African ancestry reveals a common tagging SNP. PLoS One 2008, 3:e1746.

13. Vasan SK, Fall T, Neville MJ, Antonisamy B, Fall CH, Geethanjali FS, Gu HF, Raghupathy P, Samuel P, Tohomas N, Brismar K, Ingelsson E, Karpe F: Associations of Variants in FTO and near MC4R with obesity traits in South Asian Indians. Obesity.

14. Hotta K, Kitamoto T, Kitamoto A, Mizusawa S, Matsuo T, Nakata Y, Kamohara S, Miyatake N, Kotani K, Komatsu R, Itoh N, Mineo I, Wada J, Yoneda M, Nakajima A, Funahashi T, Miyazaki S, Tokunaga K, Masuzaki H, Ueno T, Hamaguchi K, Tanaka K, Yamada K, Hanafusa T, Oikawa S, Yoshimatsu H, Sakata T, Matsuzawa Y, Nakao K, Sekine A: Association of variations in the FTO, SCG3 and MTMR9 genes with metabolic syndrome in a Japanese population. J Hum Genet 2011, 56:647-651.

15. Hennig BJ, Fulford AJ, Sirugo G, Rayco-Solon P, Hattersley AT, Frayling TM, Prentice AM: FTO gene variation and measure of body mass in an African population. BMC Med Genet 2009, 10:21.

16. Adeyemo A, Chen G, Zhou J, Shriner D, Doumatey A, Huang H, Rotimi C: FTO genetic variation and association with obesity in West African and African Americans. Diabetes 2010, 59:1549-1554.

17. Nock NL, Plummer SJ, Thompson CL, Casey G, Li L: FTO polymorphisms are associated with adult body mass index (BMI) and colorectal adenomas in African-Americans. Carcinogenesis 2011, 32:748-756.

18. Li H, Wu Y, Loos RJ, Hu FB, Liu Y, Wang J, Yu Z, Lin X: Variants in the fat mass- and obesity- associated (FTO) gene are not associated with obesity in a Chinese Han population. Diabetes 2008, 57:264-268.

19. Ohashi J, Naka I, Kimura R, Natsuhara K, Yamauchi T, Furusawa T, Nakazawa M, Ataka Y, Patarapotikul J, Nuchnoi P, Tokunaga K, Ishida T, Inaoka T, Matsumura Y, Ohtsuka R: FTO polymorphism in oceanic populations. J Hum Genet 2007, 52:1031-1035.

20. Oppert JM, Vohl MC, Chagnon M, Dionne FT, Cassard-Doulcier AM, Ricquier D, Pérusse L, Bouchard C: DNA polymorphism in the uncoupling protein (UCP) gene and human body fat. Int J Obes Relat Metab Disord 1994, 18:526-531.

21. Clement K, Ruiz J, Cassard-Doulcier AM, Bouillaud F, Ricquier D, Basdevant A, Guy-Grand B, Froguel P: Additive effect of A/G (-3826) variant of the uncoupling protein gene and the trp64arg mutation of the beta 3adrenergic receptor gene on weight-gain in morbid-obesity. Int $J$ Obes Relat Metab Disord 1996, 20:1062-1066.

22. Ravussin E, Lillioja S, Knowler WC, Christin L, Freymond D, Abbott WG, Boyce $\mathrm{V}$, Howard BV, Bogardus $\mathrm{C}$ : Reduced rate of energy expenditure as risk factor for body weight gain. N Engl J Med 1988, 318:467-472.

23. Kozak LP, Harper ME: Mitochondrial uncoupling proteins in energy expenditure. Annu Rev Nutr 2000, 20:339-363.

24. Heilbronn LK, Kind KL, Pancewicz E, Morris AM, Noakes M, Clifton PM: Association of $-3826 \mathrm{G}$ variant in uncoupling protein-1 with increased BMI in overweight Australian women. Diabetologia 2000, 43:242-244.

25. Kim KS, Cho DY, Kim YJ, Choi SM, Kim JY, Shin SU, Yoon YS: The finding of new genetic polymorphism of UCP-1 A-1766G and its effects on body fat accumulation. Biochim Biophys Acta 2005, 1741:145-155.

26. Shin HD, Kim KS, Cha MH, Yoon Y: The effects of UCP-1 polymorphisms on obesity phenotypes among Korean female subjects. Biochem Biophys Res Commun 2005, 335:624-630.

27. Bastos-Rodrigues $L$, Pimenta JR, Pena SDJ: The genetic structure of human populations studied through short insertion-deletion polymorphisms. Ann Human Genet 2006, 70:658-665.

28. Yang W, Kelly T, He J: Genetic epidemiology of obesity. Epidemiol Rev 2007, 29:49-61.

29. Loos RJF, Bouchard C: FTO: the first gene contributing to common forms of human obesity. Obesity Rev 2008, 9:246-250.

30. Andreasen CH, Stender-Petersen KL, Mogensen MS, Torekov SS, Wegner L, Andersen G, Nielsen AL, Albrechtsen A, Borch-Johnsen K, Rasmussen SS, Clausen JO, Sandbaek A, Lauritzen T, Hansen L, Jørgensen T, Pedersen O, Hansen T: Low physical activity accentuates the effect of FTO rs9939609 polymorphism on body fat accumulation. Diabetes 2008, 57:95-101.
31. Gerken T, Girard CA, Tung YC, Webby CJ, Saudek V, Hewitson KS, et al: The obesity-associated FTO gene encodes a 2-oxoglutarate-dependent nucleic acid demethylase. Science 2007, 308:1469-1472.

32. Cecil JE, Tavendale R, Watt P, Hetherington MM, Palmer CNA: An obesityassociated FTO gene variant and increased energy intake in children. N England J Med 2008, 359:2558-2566.

33. Jia JJ, Tian YB, Cao ZH, Tao LL, Zhang X, Gao SZ, Ge CR, Lin QY, Jois M: The polymorphisms of UCP1 genes associated with fat metabolism, obesity and diabetes. Mol Biol Rep 2010, 37:1513-1522.

34. Ricquier D, Bouillaud F, Toumelin P, Mory G, Bazin R, Arch J, Pénicaud L: Expression of uncoupling protein mRNA in thermogenic or weakly thermogenic brown adipose tissue. Evidence for a rapid betaadrenoreceptor-mediated and transcriptional regulated step during activation of thermogenesis. J Biol Chem 1986, 261:13905-13910.

35. Bouillaud F, Villarroya F, Hentz E, Raimbault S, Cassard AM, Ricquier D: Detection of brown adipose tissue uncoupling protein mRNA in adult patient by a genomic probe. Clin Sci 1988, 71:291-297.

36. Garruti G, Ricquier D: Analysis of uncoupling protein and its mRNA in adipose tissue deposits of adult humans. Int J Obes Relat Metab Disord 1992, 16:383-390

37. Lowell BB, Flier JS: Brown adipose tissue, beta 3-adrenergic receptors, and obesity. Annu Rev Med 1997, 48:307-316.

38. Urhammer SA, Hansen T, Borch-Johnsen K, Pedersen O: Studies of synergistic effect of the trp/Arg64 polymorphism of the b3-adrenergic receptor gene and $-3826 \mathrm{~A} / \mathrm{G}$ variant of the uncoupling protein-1 gene on features of obesity and insulin resistance in a population-based sample of 379 young Danish subjects. J Clin Endocrinol Metab 2000, 85:3151-3154

39. van Rossun CT, Hoebee B, Seidell JC, Bouchard C, van Baak MA, de Groot CP, Chagnon M, de Graaf C, Saris WH: Genetic factors as predictors of weight-gain in young adult Dutch men and women. Int I Obes Relat Metab Disord 2002, 26:517-528.

40. Kieć-Wilk B, Wybrańska I, Malczewska-Malec M, Leszczyńska-Gołabek L, Partyka L, Niedbał S, Jabrocka A, Dembińska-Kieć A: Correlation of the $-3826 \mathrm{~A} / \mathrm{G}$ polymorphism in the promoter of the uncoupling protein 1 gene with obesity and metabolic disorders in obese families from southern Poland. J Physiol Pharmacol 2002, 53:477-490.

41. Sarzynski MA, Jacobson P, Rankinen T, Carlsson B, Sjöström L, Bouchard C, Carlsson LM: Associations of markers in 11 obesity candidate genes with maximal weight loss and weight regain in SOS bariatric surgery cases. Int J Obes 2011, 35:676-683.

42. Parra FC, Amado RC, Lambertucci JR, Rocha J, Antunes CM, Penna SD: Color and genomic ancestry in Brazilians. Proc Natl Acad Sci 2003, 100:177-182.

43. Frazer KA, Murray SS, Schork NJ, Topol EJ: Human genetic variation and its contribution to complex traits. Nat Rev Genet 2009, 10:241-251.

doi:10.1186/1471-2350-13-101

Cite this article as: Ramos et al: The contribution of FTO and UCP-1 SNPs to extreme obesity, diabetes and cardiovascular risk in Brazilian individuals. BMC Medical Genetics 2012 13:101

\section{Submit your next manuscript to BioMed Central and take full advantage of:}

- Convenient online submission

- Thorough peer review

- No space constraints or color figure charges

- Immediate publication on acceptance

- Inclusion in PubMed, CAS, Scopus and Google Scholar

- Research which is freely available for redistribution 